\title{
What's really happening among the elderly population?
}

\author{
Mohammed Ali Fakhro* \\ Coordinator of Physical Therapy Department, Lebanese German University, Lebanon \\ ${ }^{*}$ Corresponding author: Mohammed Ali Fakhro, Coordinator of Physical Therapy Department, Lebanese German University, Tyre Campus, Tyre, \\ Lebanon
}

Submission: 眥 March 29, 2018; Published: 眥 May 21, 2018

\section{Introduction}

Global population is rapidly ageing due to an increase in life expectancy and a reduction in fertility rates, while the number of years lived with disability is also on the rise [1-3,5]. In 2010, an estimated 524 million people were aged 65 or older, $8 \%$ of the world's population. By 2050 this is expected to nearly triple to 1.5 billion, representing about $16 \%$ of the world's population [1]. In the United Kingdom alone, there are about 10 million people aged over 65 , a number expected to rise by 1.1 million by 2020 [6].

Ageing presents both challenges and opportunities. It will increase demand for primary health care and long-term care, require a larger and better trained workforce and intensify the need for environments to be made more age-friendly. In addition, it is well known that age is an independent risk factor for the development of non-communicable diseases (NCDs) such as cardiovascular disease, cancer, diabetes and dementia [1].

Even without NCDs, function and independence generally decline in older age as a result of reductions in cognitive and physical capacity [7-8], where reduced or impaired mobility plays an important role in poorer quality of life (QOL) among those living in residential care homes. Approximately, $90 \%$ of people in longterm care have some type of reduced mobility [17], with about $40 \%$ of those with dementia losing their ability to walk each year [18].

Now more than ever it is vital to investigate ways to encourage "aging well" [9] or "Active Ageing", which refers to older adults being enabled to continue participating in "social, economic, cultural, spiritual and civic affairs" and maintain a good QOL [10].

Performing sufficient physical activity (PA) is a primary modifiable determinant of health especially pertinent to active ageing because it is known to have vast mental and physical health benefits for people of all ages [11,12]. Therefore, with or without NCDs, increasing PA levels is one of the primary targets of the World Health Organization (WHO) [13].

However, despite the known benefits of regular PA [14], 23\% of adults globally are insufficiently active, with some high income countries having inactivity rates of up to $54 \%$ [15]. In addition, inactivity rates increase with age, with around two-thirds of those between 65-74 years and three-quarters of those over 75 years not meeting PA guidelines of at least $150 \mathrm{~min} /$ week of moderate intensity activity in either the USA [16] or Australia [17], and those living in care homes still spend most of their time in wheelchairs or in bed [19].

Adding to that according to the European Opinion Research Group, 97.4\% of people aged 65 and over do not meet recommendations for PA to achieve health benefits [22]. In the older Polish population, the most popular use of free time is watching television and listening to the radio (30.2\%), followed by reading $(15.5 \%)$, passive recreation $(13.1 \%)$, religious practices (11.9\%), and gardening (8.7\%) [23].

On the other hand, aging is one of the greatest social and economic challenges facing the European Union (EU). According to a 2011 report by the Central Statistical Office in Poland, nearly $40 \%$ of people older than 70 years of age have problems with basic self-care: more than 1.8 million have difficulty self-washing, and more than 1.6 million have difficulty dressing and undressing independently $[4,20]$.

Many behavioral change theories highlighted in addition the importance of social factors such as social support (SS) and social connectedness in maintaining and/or initiating behavior change in PA with older adults [24-29]. Furthermore, the WHO identifies SS as a key determinant of Active Ageing [10].

\section{References}

1. World Health Organisation (2011) US National Institute of Aging. Global Health and Ageing. World Health Organisation, Geneva, Switzerland.

2. Kassebaum NJ, Arora M, Barber RM, Bhutta ZA, Carter A, et al. (2016) Global, regional, and national disability-adjusted life-years (DALYs) for 315 diseases and injuries and healthy life expectancy (HALE) 19902015: a systematic analysis for the Global Burden of Disease Study 2015. Lancet 388(10053): 1603-1658.

3. Vos T, Allen C,Arora M, Barber RM, Bhutta ZA, etal. (2016) Global, regional, and national incidence, prevalence, and years lived with disability for 310 diseases and injuries, 1990-2015: a systematic analysisfor the Global Burden of Disease Study 2015. Lancet 388(10053): 1545-1602.

4. Bernd R, Doyle Y, Grundy E, McKee M (2009) How can health systems respond to population ageing? WHO, 1997-8073, Denmark. 
5. Office for National Statistics (2013) What does the 2011 Census tell us about older people.

6. Kasneci D (2007) Active Ageing: The EU policy response to the challenge of population ageing. European papers on the new welfare 8: 32-61.

7. Balogun JA, Akindele KA, Nihinlola JO, Marzouk DK (1994) Age-related changes in balance performance. Disabil Rehabil 16(2): 58-62.

8. Singh MAF (2002) Exercise comes of age: rationale and recommendations for a geriatric exercise prescription. J Gerontol Ser A Biol Med Sci 57(5): M262-M282.

9. Kendig H, Browning CJ, Thomas SA, Wells Y (2014) Health, lifestyle, and gender influences on aging well: an Australian longitudinal analysis to guide health promotion. Front Public Health 2: 70.

10. World Health Organization (2002) Active Ageing: A Policy Framework, Geneva, Switzerland.

11. De Souto Barreto P (2009) Exercise and health in frail elderly people: a review of randomized controlled trials. Eur Rev Aging Phys Act 6(2): 75-87.

12. Paterson DH, Warburton DE (2010) Review Physical activity and functional limitations in older adults: a systematic review related to Canada's Physical Activity Guidelines. Int J Behav Nutr Phy 7(38): 1-22.

13. World Health Organization (2010) Global Recommendations on Physical Activity for Health. World Health Organization, Geneva, Switzerland.

14. Organization WH (2010) Global recommendations on physical activity for health.

15. Organisation WH (2015) Prevalence of insufficient physical activity among adults. Global Health Observatory data repository. World Health Organisation, Geneva, Switzerland.

16. Schoenborn C, Adams P, Peregoy J (2013) Health Behaviours of Adults: United States. In: Statistics NCfH (Eds.), US Department of Health and Human Services. Maryland, USA.

17. Australian Bureau of Statistics (2013) Australian Health Survey: Physical Activity.

18. Williams S, Williams CS, Zimmerman S, Sloane P, Preisser J, Boustani M, et al. (2005) Characteristics associated with mobility limitation in LTC residents with dementia. Gerontologist 45(Suppl 1): 62-67.
19. Slaughter SE, Eliasziw M, Morgan D, Drummond N (2010) Incidence and predictors of excess disability in walking among nursing home residents with middle-stage dementia: a prospective cohort study. Int Psychogeriatr 23(1): 54-64.

20. Bates Jensen BM, Schnelle JF, Alessi CA, Al Samarrai NR, Levy Storms L (2004) The effects of staffing on in-bed times of nursing home residents. J Am Geriatr Soc 52(6): 931-938.

21. Olson EV, Thompson LF, McCarthy JA, Johnson BJ, Edmonds RE, et al. (1967) The hazards of immobility. Am J Nurs 67: 780-797.

22. European Commission (2003) Physical Activity.

23. Główny Urząd Statystyczny (2006) Mały Rocznik Statystyczny RP, Warszawa.

24. Fuller BG, Stewart Williams JA, Byles JE (2010) Active living-the perception of older people with chronic conditions. Chronic Illness 6(4): 294-305.

25. McAuley E, Jerome GJ, Marquez DX, Elavsky S, Blissmer B (2003) Exercise selfefficacyin older adults: Social, affective, and behavioral influences. Ann Behav Med 25(1): 1.

26. Ayotte BJ, Margrett JA, Hicks Patrick J (2010) Physical activity in middleaged and young-old adults: the roles of self-efficacy, barriers, outcome expectancies, self-regulatory behaviors and social support. J Health Psychol 15(2): 173-185.

27. Van Stralen MM, De Vries H, Mudde AN, Bolman C, Lechner L (2009) Determinants of initiation and maintenance of physical activity among older adults: a literature review. Health Psychol Rev 3(2): 147-207.

28. Hansen BH, Ommundsen Y, Holme I, Kolle E, Anderssen SA (2014) Correlates of objectively measured physical activity in adults and older people: a crosssectional study of population-based sample of adults and older people living in Norway. Int J Public Health 59(2): 221-230.

29. Koeneman MA, Verheijden MW, Chinapaw MJM, Hopman Rock M (2011) Determinants of physical activity and exercise in healthy older adults: A systematic review. Int J Behav Nutr Phys Act 8: 142.
Creative Commons Attribution 4.0

International License

For possible submissions Click Here

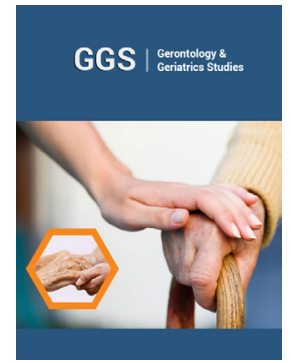

Gerontology \& Geriatrics Studies

\section{Benefits of Publishing with us}

- High-level peer review and editorial services

- Freely accessible online immediately upon publication

- Authors retain the copyright to their work

- Licensing it under a Creative Commons license

- Visibility through different online platforms 